
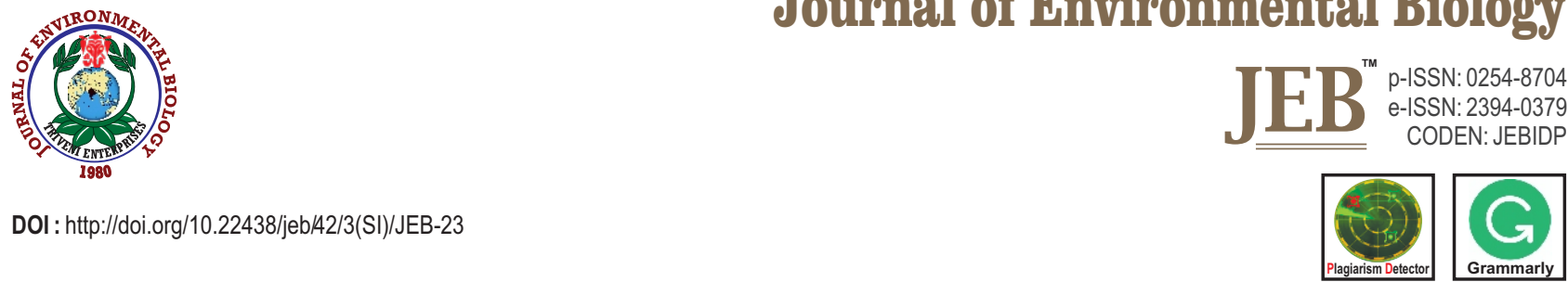

\title{
Reproductive traits of Goby Glossogobius sparsipapillus Akihito and Meguro, 1976 in Tra Vinh Province, Vietnam
}

\author{
N.K. Ho ${ }^{1}$, T.M. Nguyen ${ }^{2}$ and Q.M. Dinh ${ }^{3 *}$ \\ 'School of Agriculture and Aquaculture, Tra Vinh University, Tra Vinh, 940000, Vietnam \\ ${ }^{2}$ The Centre of Hi-Tech Application in Agriculture, Ben Tre, 930000, Vietnam \\ ${ }^{3}$ Department of Biology, School of Education, Can Tho University, Can Tho, 900000, Vietnam \\ *Corresponding Author Email : dmquang@ctu.edu.vn
}

\section{Abstract}

Aim: This study was conducted to contribute data on the reproductive biology such as sex proportion, spawning season and pattern, fecundity and its relation to fish size, and length at first mature of the commercial fish Glossogobius sparsipapillus in Tra Vinh province, Vietnam.

Methodology: Fish was collected monthly using trawling nets at four sampling sites during dry and wet seasons between July 2019 to June 2020 . Next, fish was stored in ice before transporting to the laboratory. In laboratory, total length, body weight, and sex before removing gonads were examined histologically.

Results: Female G. sparsipapillus (806 individuals) out numbered males (591 individuals). This goby was a multi-spawner as different developmental stages of oocytes and spermatocytes were present in the cross-section of testes and ovaries. A combined analysis of frequency of mature ovaries and GSI showed that this goby could spawn throughout the study period with the mean peak from July to October. The batch fecundity was 17,537 SE and related positively to fish length and weight, indicating it increased as fish grew.

Interpretation: This study results in an enhanced understanding of this species' reproductive biology for better sustainable management and brood stock study in studied regions.

Key words: Fecundity, Glossogobius sparsipapillus, Multiples pawner, Reproductive traits

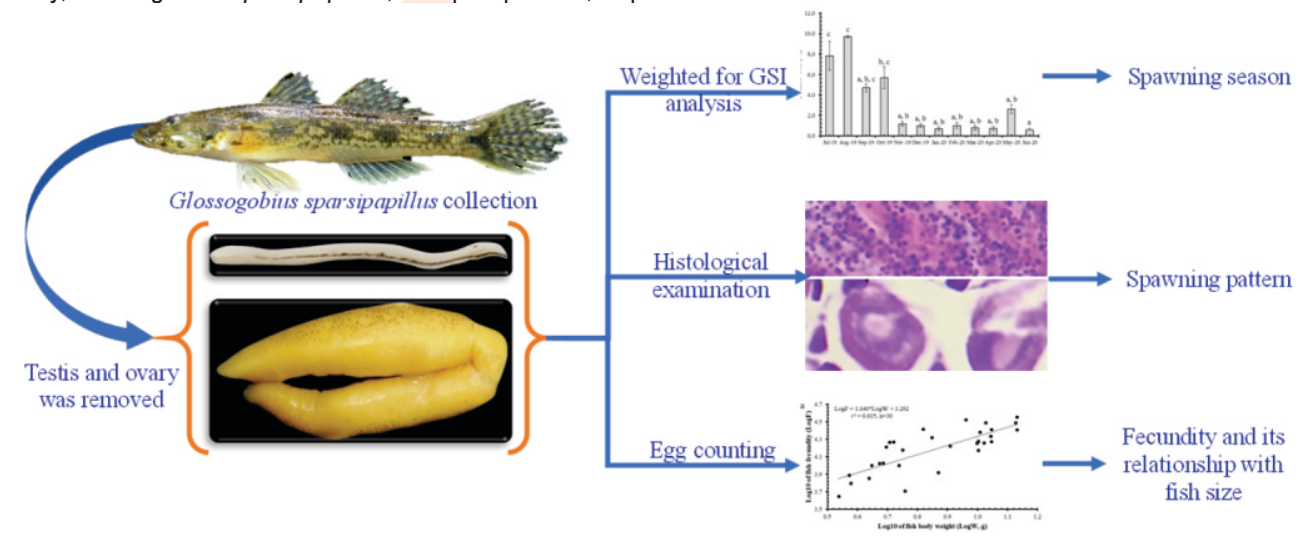

How to cite : Ho, N.K., T.M. Nguyen and Q.M. Dinh: Reproductive traits of Goby Glossogobius sparsipapillus Akihito and Meguro, 1976 in Tra Vinh Province, Vietnam. J. Environ. Biol., 42, 879-886 (2021). 


\section{Introduction}

Wootton (1990) indicated that semelparity and iteroparity are two main reproductive strategies. Iteroparous is found in most gobiid species (Miller, 1984; Dinh et al., 2016; Dinh et al., 2020). There is a strong relationship between the strategy of reproduction and fishery (Miller, 1984; Komolafe and Arawomo, 2007; Dinh et al., 2020). Fontoura et al. (2009) and Teichert et al. (2014) noted that the information about body size when fish was mature firstly and batch fecundity played a vital role in managing the fish stock. However, studies on the reproductive biology of gobies is still fragmented in the Mekong Delta, especially in the Tra Vinh province, a favourable habitat for gobiid communities, which is being over exploited (Trinh and Tran, 2012).Consequently, the need for practical strategies to recover fish resources is urgently required.

The genus Glossogobius has 29 species (Hoese et al., 2015), and only three species $G$ giuris, G. aureus and G.sparsipapillus are recorded in the Mekong Delta, Vietnam, including Tra Vinh province (Tran et al., 2013). The goby G.sparsipapillus, described firstly by Akihito and Meguro (1976), distributes widely distributed in the Indo-Pacific regions from brackish to freshwater (Froese and Pauly, 2019; Riede, 2004; Talwar and Jhingran, 1991; Rainboth, 1996). In Tra Vinh, it is a high economic value fish. Although the fish population size tends to decrease as it is caught for food supply, however, studies on the external morphology, otolith, habitat environment, and food composition (Tran et al., 2013; Rainboth, 1996; Nguyen and Dinh, 2020; Nguyen et al., 2020) is meagre. Meanwhile, the reproductive traits of this goby species has been limited and fragmented. Hence, this study was carried out to determine the reproductive biology of $G$. sparsipapillus, including ratio of male and female; spawning season and pattern; fecundity; and relationship between fish body size and batch fecundity in Tra Vinh province, South Vietnam. The findings will be used for brood stock study and fisheries management.

\section{Materials and Methods}

Study site and fish collection: The study was performed in Tra Vinh province, Southern Vietnam from July 2019 to June 2020. There were two typically dry and wet seasons, with monthly rainfall of $400 \mathrm{~mm}$ in the wet season (June-December). Besides, there was a significant decrease in precipitation during dry season (Jan-May). The temperature in these provinces was $\sim 27^{\circ} \mathrm{C}$.

The samples of $G$. sparsipapillus were caught monthly using trawling nets, from four sampling sites: Long Huu - Duyen Hai, Kim Hoa - Cau Ngang, Da Loc - Chau Thanh and Ham Tan Tra Cu. In each site, trawling nets were retrieved after 2-3 hrs setting up. This activity was performed continuously for a total 48hrs in each place. (Dinh et al., 2015). Fish specimens were kept in ice and transported to the laboratory.

Fish analysis: Fish specimens were separated into males and females using genital papilla (triangle in males and oval in females) before determining total length $(T L)($ nearest $0.1 \mathrm{~cm})$ and weight (nearest $0.01 \mathrm{~g}$ )(Nguyen and Dinh, 2020). The testis and ovarian maturation stages of Gobiusniger documented by Vesey and Lang ford (1985) were used to classify the developmental stages of testis and ovary of G. sparsipapillus. Gonadal stages were histologically examined using the staining procedure described by Carleton et al. (1980). The gamete terminological described by Yamamoto (1956) and Yamazaki (1965) was applied to determine the oocyte and spermatocyte developmental stages.

Gonadosomatic index (GSI) was calculated by the equation $\mathrm{GSI}=100 \times \mathrm{G} / \mathrm{W}$, where $\mathrm{G}$ is the gonad weight and $\mathrm{W}$ is the fish body weight (Sturm, 1978). This goby's spawning pattern and season were estimated by Dinh and Le (2017) method. The batch fecundity was determined by the equation $F=(n \times G) / g$, where $n$ is the number of eggs in sub-sample; $g$ is the weight of sub-sample; and $\mathrm{G}$ is the ovarian weight (Bagenal, 1967).

Data analysis: The difference in sex ratio was quantified using $c^{2}$. One-way ANOVA quantified the monthly variation of GSI. The relationships between batch fecundity and fish length and weight were quantified by logarithmic regression (Metin et al., 2011). The SPSS software v.21 was used for all tests with a significant level of $5 \%$.

\section{Results and Discussion}

In this study, total 1,397 fishes (806 females and 591 males) were collected monthly from Tra Vinh. The female G.sparsipapillus out numbered males $\left(c^{2}=34.52, P<0.001\right)$. Likewise, another gobiid species, Gobius vittatus, showed a significantly higher number in females than males because males played a chief role in building nest during breeding season. (Kovačić, 2007). In contrast, the more active males outnumbered females in Periophthalmodon septemradiatus (Dinh et al., 2020). While some gobiid species Boleophthalmus boddarti (Dinh et al., 2015), Periophthalmodon schlosseri (Dinh, 2016b; Tran et al., 2019), Trypauchen vagina (Dinh, 2016a), Parapocyptes serperaster (Dinh et al., 2016), Butis butis (Dinh and Le, 2017), and Stigmaotogbius pleurostigma (Dinh and Tran, 2018) found in Mekong Delta were found in 1:1 of male and female ratio. It seems that reproductive behavior was the leading cause for the change in the gender ratio of these gobiid species.

The stage I testes comprised mostly of spermatogonia (Fig. 2e). Besides few spermatogonia, several primary spermatocytes (SC1) and secondary spermatocytes (SC2) were found at stage II testes (Fig. 2f). Besides SC1 and SC2, there were spermatids (ST) at stage III sperm ducts (Fig. 2g). The 

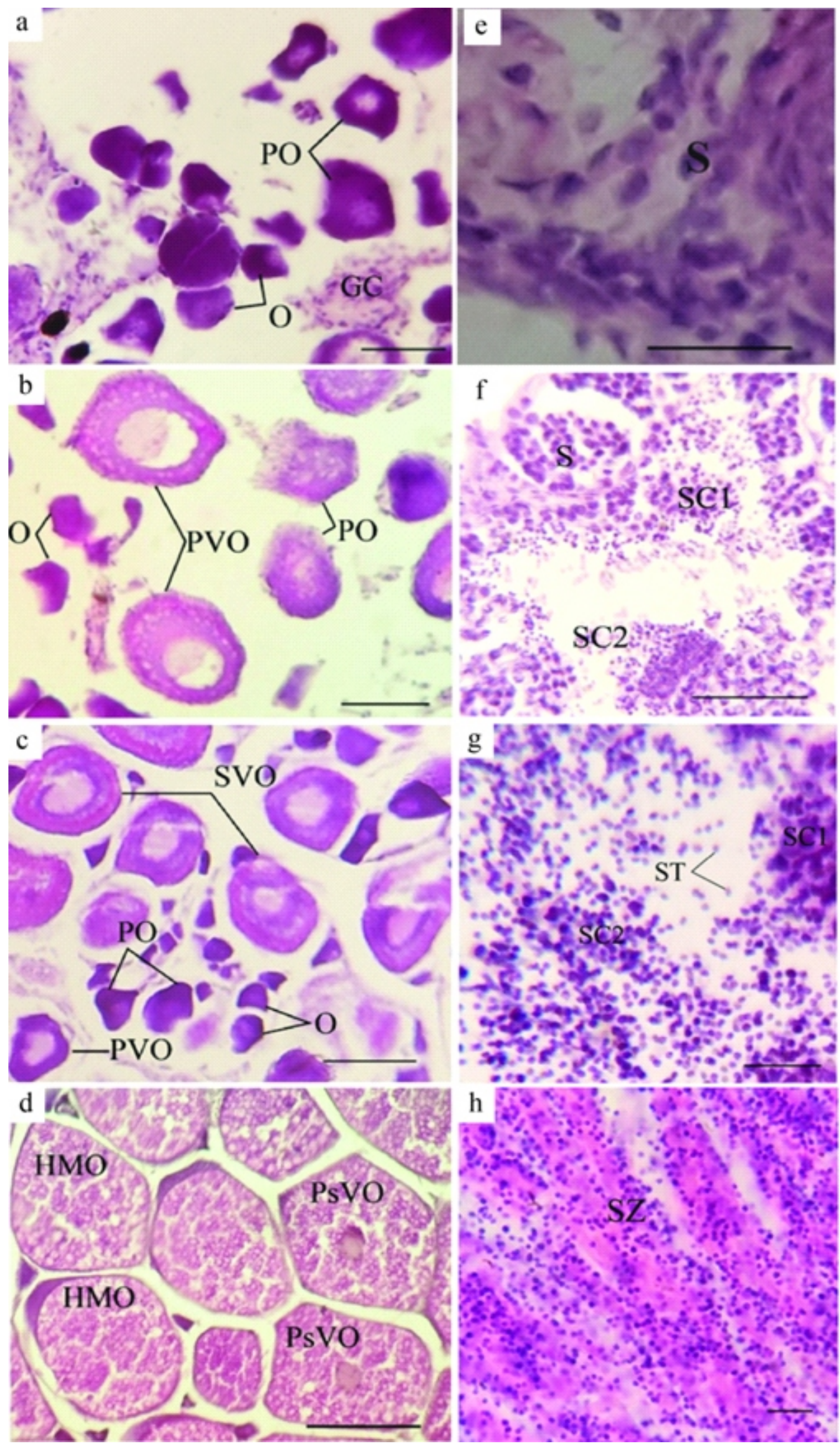

Fig. 2: Ovarian and testis cross-sections of Glossogobius sparsipapillus (a, b, c, and d were stages I, II, III, and IV of ovaries; e, f, g, and h were stages I, II, III and IV of testes, respectively). GC: Germ cells, O: oogonia, PO: primary oocyte, PVO: primary vitellogenic oocytes, SVO: secondary vitellogenic oocytes, PsVO: post vitellogenic oocytes, and HMO: hydrated mature oocytes; S: spermatogonia, SC1: primary spermatocytes, SC2: secondary spermatocytes, ST: spermatid, and SZ: spermatozoa. Scale bar $100 \mathrm{~m}$ and $50 \mathrm{~m}$ for ovary and testis respectively. 

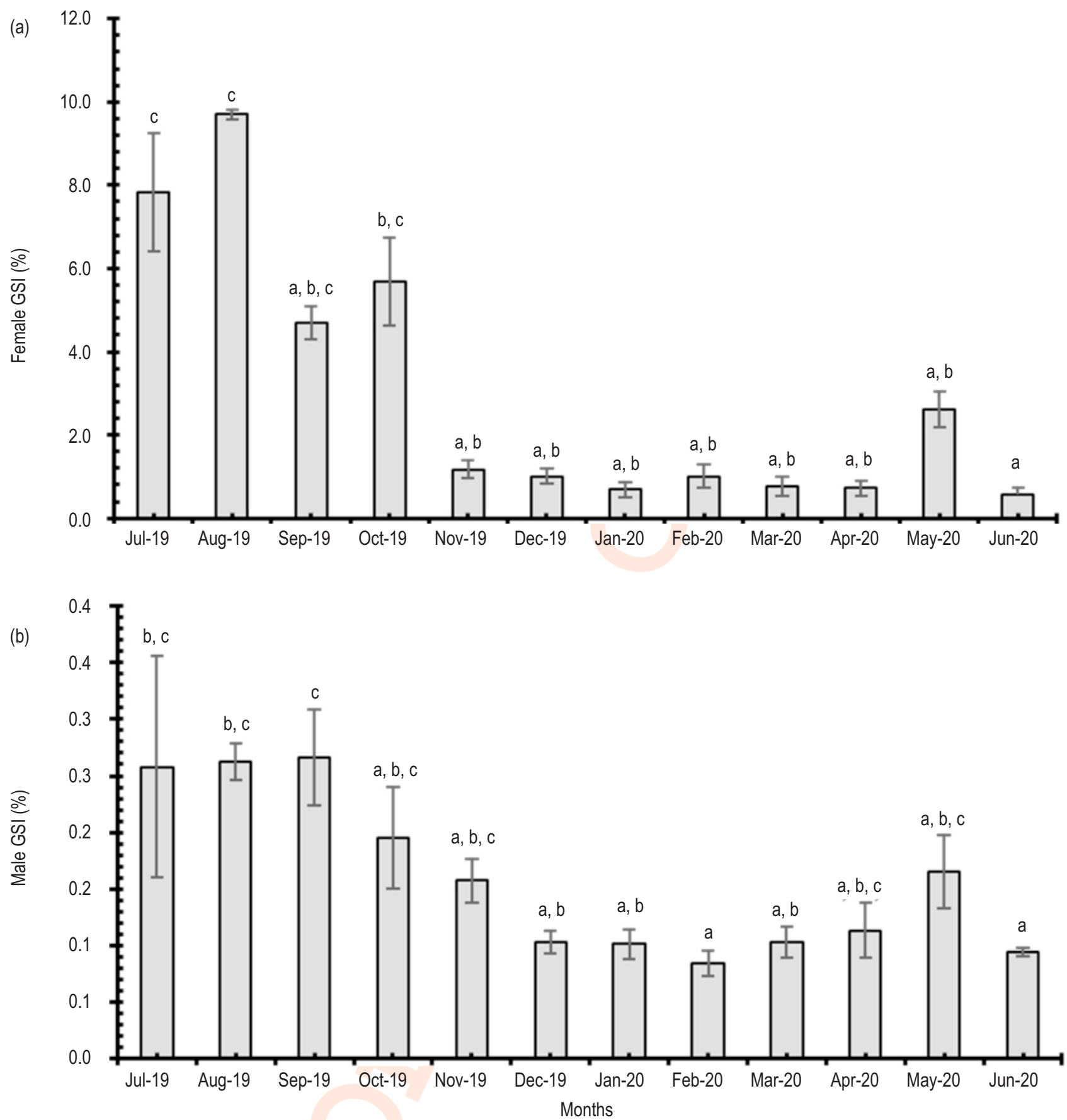

Fig. 3 : The 12-month variation of gonadosomatic index of female (a) male and (b) Glossogobius sparsipapillus. Vertical line represent standard error of means. Different letters ( $a, b$, and $c)$ represents significant difference in GSI.

mature stage of IV consisted of ST, spermatozoa (SZ), and few SC2 (Fig. 2h). At this study, stage $V$ and VI testes were not found in fishes, It may be due to their movement from the spawning ground.

The type of oocytes, including germ cells (GS), oogonia $(\mathrm{O})$, and primary oocytes $(\mathrm{PO})$ were found in stage I of ovaries
(Fig. 2a). Primary vitellogenic oocytes (PVO) with cytoplasm containing some yolk granules were present in stage II ovaries, besides germ cells, oogonia, and primary oocytes (Fig. 2b). The oogonia and primary oocytes, stage III ovaries consisted mainly of primary vitellogenic oocytes and few secondary vitellogenic oocytes (SVO) with a nucleus and yolk accumulation (Fig. 2c). At stage IV, ovaries contained mainly of post vitellogenic oocytes 

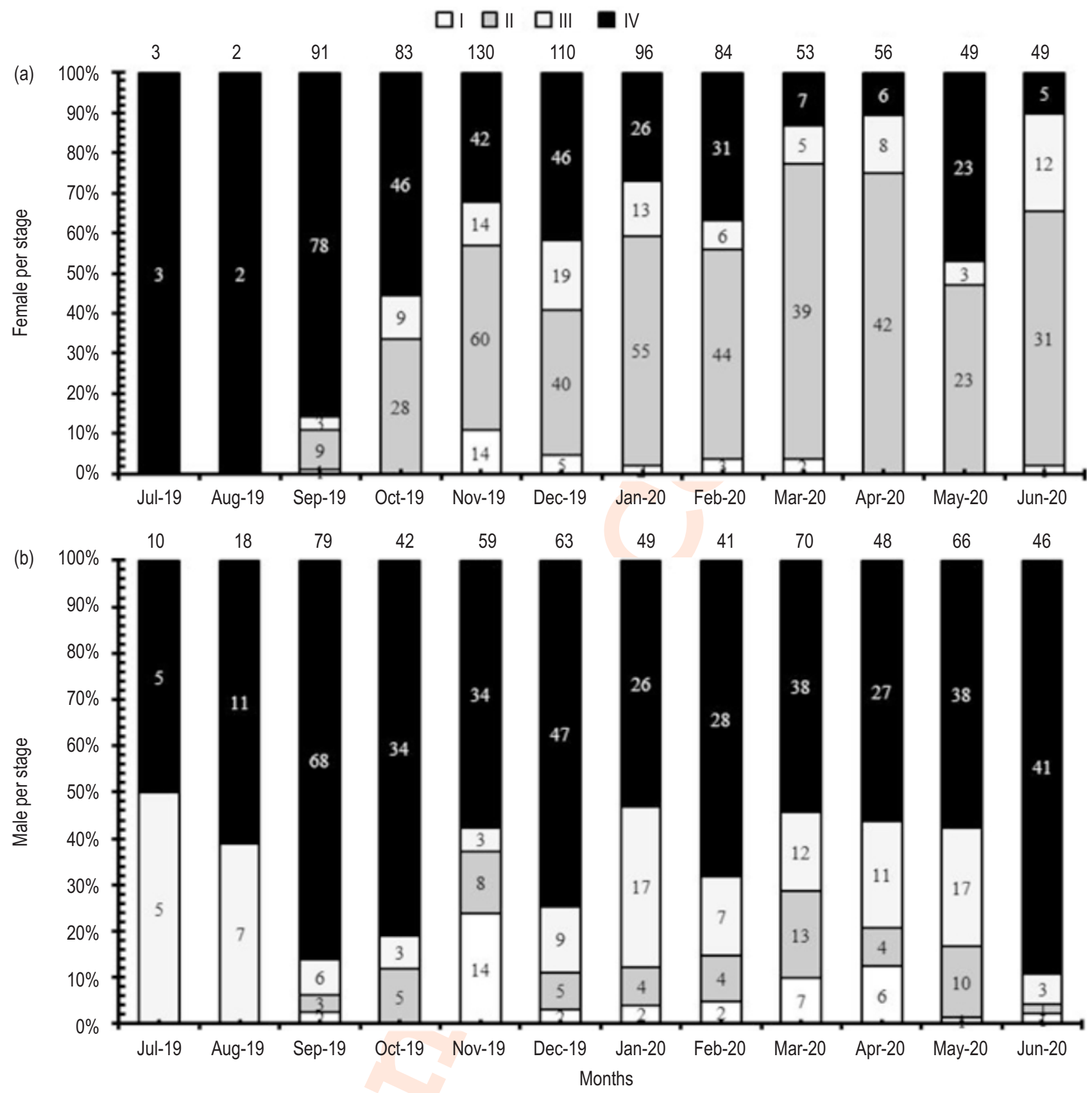

Fig. 4 : The 12-month variation of gonad compositions of female (a) and male (b) Glossogobiussparsipapillus. Top number: total fish collection; Number in a column: fish at each gonad development stage collection.

with the nucleus (PsVO) and hydrated oocytes without nucleolus together with some primary oocytes, primary vitellogenic oocytes and secondary vitellogenic oocytes (Fig. 2d). Similar to testes, fishes at stage $V$ and VI ovaries were not found, which resulted due to their moving away from the spawning ground.

The gonadosomatic index (GSI) of this goby fluctuated monthly throughout the study period, reaching higher values during July-October and lower one during the rest of study period (one-way ANOVA, $F_{\text {female }}=17.27, F_{\text {male }}=4.66, P<0.001$ for two cases) (Fig. 3) with the appearance of ovaries and testes during the study period (Fig. 4), this goby could reproduce monthly and concentrate during the main rainy season from July to October due to height value of GSI at that time. Also, Periophthalmus barbarus in Nigeria spawned mainly in May when the habitat receives sufficient nutrients (Udo, 2002; Etimet al., 2002) and 

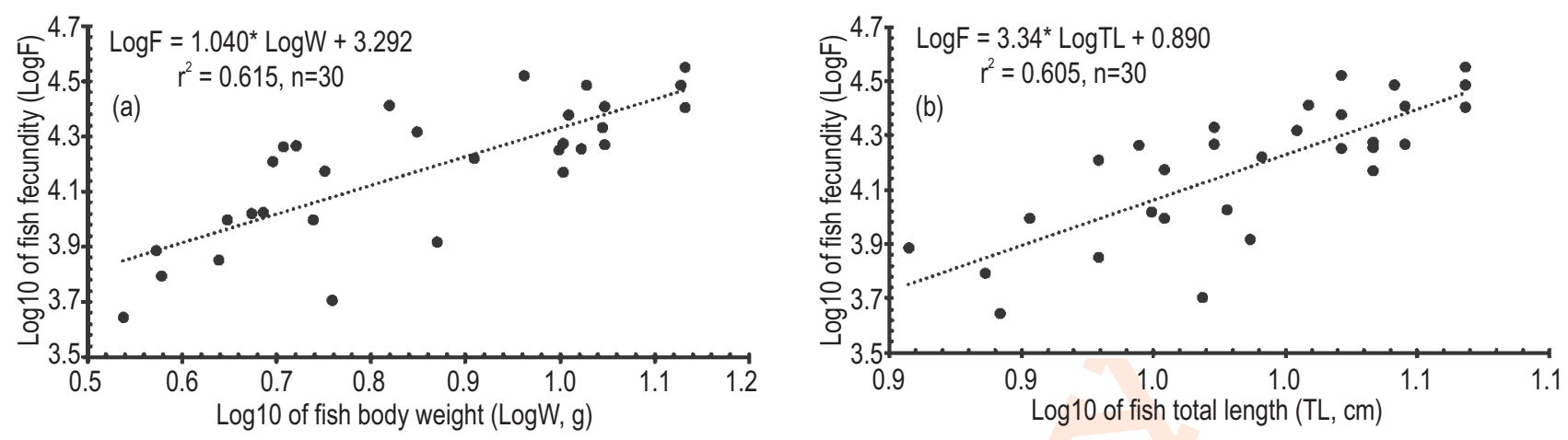

Fig. 5 : Relationships between fecundity and weight (a) and total length (b) of Glossogobius sparsipapillus

Periophthalmodon schlosseri in Malaysia reproduced throughout southwest monsoon season (from April to October) due to availability of plenty food in their habitat at the time (Mazlan and Rohaya, 2008). Besides, Boleophthalmus boddarti (Dinh et al., 2015), Parapocryptes serperaster(Dinh et al., 2016), Trypauchen vagina (Dinh, 2018), and Stigmatogobius pleurostigma (Dinh and Tran, 2018), in the Mekong Delta, spawned mainly due to availability of food sources the estuarine region. To different living environment, the gobies such as Neogobius melanostomus (Macinnis and Corkum, 2000), Crystallogobius linearis (Caputo et al., 2003) and Amblygobius phalaena (Takegaki, 2000), they spawned during a period from May to October. A few gobiid speices occuring in and out habitats of G. sparsipapillus, including Valenciennea strigata (Reavis, 1997), Butisbutis (Dinh and Le, 2017), Periophthalmodon schlosseri (Tran et al., 2019), and Periophthalmodon septemradiatus (Dinh et al., 2020) could spawn throughout the year.

Due to deposition of eggs several times during breeding season, most gobies were multiple spawners, (Longhurst and Pauly, 1987).Similarly, G. sparsipapillus, in study, was a multiple reproducer due to the appearance of primary vitellogenic oocytes, secondary vitellogenic oocytes, post vitellogenic oocytes and hydrated mature oocytes in mature ovaries. This fish released sperm during the spawning period since the appearance of different developmental stages of sperms such as primary spermatocytes, secondary spermatocytes, spermatid and spermatozoa were found in mature testes. The serial spawning strategy was also found in some other gobies Boleophthalmus boddarti (Dinh et al., 2015), Parapocryptes serperaster (Dinh et al., 2016), Trypauchen vagina (Dinh, 2018), and Stigmatogobius pleurostigma (Dinh and Tran, 2018), Periophthalmodon schlosseri (Tran et al., 2019), and Periophthalmodon septemradiatus (Dinh et al., 2020) living in the Mekong Delta.

The batch fecundity of $G$. sparsipapillus ranged from 4,415 eggs per female ( $3.45 \mathrm{~g} \mathrm{~W}$ and $7.8 \mathrm{~cm} \mathrm{TL}$ ) to 35.759 eggs per female (13.54 $\mathrm{g} \mathrm{W}$ and $11.7 \mathrm{~cm} \mathrm{TL}$ ). Comparing to some other gobies, the fecundity of this goby was lower than that of
Valenciennea strigata French Polynesia ( $F=60,000-160,000)$ (Reavis, 1997), Amblygobius phalaena in Nigeria ( $F=37,000$ $38,000)$ (Takegaki, 2000), but higher than that of Neogobius melanostomus in North America ( $F=84-606$ ) (Macinnis and Corkum, 2000), Crystallogobius linearis in the Adriatic Sea $(F=200-700)$ (Caputo et al., 2003), Boleophthalmus boddarti in India ( $F=2,100-12,300)$ (Chandran et al., 2014). Likely, the $F$ value of $G$. sparsipapillus was higher than other gobies living in the Mekong Delta, Southern Vietnam, including Parapocryptes serperaster in Soc Trang province ( $F=6,000-11,700)$ (Dinh et al., 2016) and Butisbutis in Bac Lieu province $(F=15,000-78,500)$ (Dinh and Le, 2017), Trypauchen vagina in Soc Trang province $(F=4,000-12,750)$ (Dinh, 2018), Stigmatogobius pleurostigma in Soc Trang province ( $F=3,100-5,650)$ (Dinh and Tran, 2018),. The $F$ value of $G$. sparsipapillus in the present study was similar to Periophthalmus barbarus in Japan $(F=900-24,000)$ (Udo, 2002, Etim et al., 2002) and some other gobies living in Southern Vietnam like Boleophthalmus boddarti in Soc Trang province ( $\mathrm{F}=$ 9,800-33,800) (Dinh et al., 2015), Periophthalmodon septemradiatus along the Hau River ( $F=969-17,536)$ (Dinh et al., 2020). The difference in between G. sparsipapillus and other gobies living in and out Tra Vinh province suggested the fecundity was species-specific and regulated by environmental conditions.

This species' batch fecundity was positively related to total length and weight because correlation coefficient was relatively high $\left(r^{2}>0.60\right.$ for two cases). This coefficient was obtained from the linear regression between batch fecundity and fish dimensions (Fig. 5). It suggested that fecundity increased with fish size and could be estimated from the given fish length or weight. Also, the positive relationship was found in some other gobiid species living out its habitat, including Neogobius melanostomus (Macinnis and Corkum, 2000), Periophthalmus barbarus (Udo, 2002; Etim et al., 2002), Crystallogobius linearis (Caputo et al., 2003), Boleophthalmus boddarti (Chandran et al., 2014). The fecundity value of some gobies living in Southern Vietnam such as Boleophthalmus boddarti (Dinh et al., 2015), Parapocryptes serperaster (Dinh et al., 2016), Butis butis (Dinh and Le, 2017), Trypauchen vagina(Dinh, 2018), Stigmatogobius 
pleurostigma (Dinh and Tran, 2018) and Periophthalmodon septemradiatus (Dinh et al., 2020) also positively related with fish total length and weight.

In conclusion, Glossogobiussparsipapillus is an iteroparous fish spawning. This goby could spawn throughout the study period and mainly from July to October. The present research provides more useful information about the reproductive characteristics of G. sparsipapillus. Moreover, it was also contributes to necessary knowledge to exploit and manage this fish resource appropriately and sustainably.

\section{Acknowledgment}

This study was fully funded by Tra Vinh University under grant contract number 134/HĐ.HĐKH-ĐHTV.

\section{Add-on Information}

Authors' contribution : N.K. Ho and T.M. Nguyen: Contributed to fish collection and manuscript writing; Q.M. Dinh: Contributed to fish collection, data analysis and manuscript writing.

Research content: The research content is original and has not been published elsewhere

\section{Ethical approval: NotApplicable}

Conflict of interest: The authors declare that there is no conflict of interest.

\section{Data from other sources: NotApplicable}

Consent to publish: All authors agree to publish the paper in Journal of Environmental Biology.

\section{References}

Akihito, P. and K. Meguro: Glossogobius sparsipapillus, a new species of goby from Viet Nam. Japanese J. Ichthyol., 23, 9-11 (1976).

Bagenal, T.B.: A short review of fish fecundity. In: The Biological Basis of Freshwater Fish Production (Ed.: S.D. Gerking). John Wiley, New York, pp. 89-111 (1967)

Caputo, V., M.L. Mesa, G. Candi and P.N. Cerioni: The reproductive biology of crystal goby with a comparison to that of the transparent goby. J. Fish Biol.,62, 375-385 (2003).

Carleton, H.M., R.A.B. Drury and E. Wallington: Carleton's Histological Technique.Oxford University Press, London, United Kingdom (1980).

Chandran, R., A.K. Jaiswar, S. Jahageerdar, N. Poojary and S. Chakraborty: A study on reproductive biology of Boleophthalmus boddarti from Mumbai region. J. Indian Fish., 41, 57-69 (2014).

Dinh, Q.M., T.T.G. Nguyen and T.K.T. Nguyen: Reproductive biology of the mudskipper Boleophthalmus boddarti in Soc Trang. Tap. Chi. Sinh. Hoc., 37, 362-369 (2015).

Dinh, Q.M.: Growth pattern and body condition of Trypauchen vagina in the Mekong Delta, Vietnam. J. Anim. Plany Sci., 26, 523-531 (2016a).
Dinh, Q.M.: Growth and body condition variation of the giant mudskipper Periophthalmodon schlosseri in dry and wet seasons. Tap chi Sinh hoc, 38, 352-358 (2016b).

Dinh, Q.M., J.G. Qin, S. Dittmann and D.D. Tran: Reproductive biology of the burrow dwelling goby Parapocryptes serperaster. Ichthyol. Res.,63, 324-332 (2016).

Dinh, Q.M. and T.T.M. Le: Reproductive traits of the duckbill sleeper Butis butis (Hamilton, 1822). Zool. Sci.,24, 452-458 (2017).

Dinh, Q.M.: Aspects of reproductive biology of the red goby Trypauchen vagina (Gobiidae) from the Mekong Delta. J. Appl. Ichthyol., 34, 103-110 (2018).

Dinh, Q.M. and T.T.N. Tran: Reproductive biological traits of the goby Stigmatogobius pleurostigma (Bleeker, 1849) from the Mekong Delta, Vietnam.Indian J. Fish.,65, 20-25(2018).

Dinh, Q.M., L.T. Tran, N.C. Ngo, T.B. Pham and T.T.K. Nguyen: Reproductive biology of the unique mudskipper Periophthalmodon septemradiatus living from estuary to upstream of the Hau River. Acta Zool.,101, 206-217 (2020).

Etim, L., R.P. King and M.T. Udo: Breeding, growth, mortality and yield of the mudskipper Periophthalmus barbarus (Linneaus 1766) (Teleostei: Gobiidae) in the Imo River estuary, Nigeria. Fish. Res.,56, 227-238 (2002).

Fontoura, N.F., A.S. Braun and P.C.C. Milani: Estimating size at first maturity (L50) from Gonadossomatic Index (GSI) data. Neotrop. Ichthyol., 7, 217-222 (2009).

Froese, R. and D. Pauly: FishBase. World Wide Web electronic publication, (2019).

Hoese, D.F., R.K. Hadiaty and F. Herder: Review of the dwarf Glossogobius lacking head pores from the Malili lakes, Sulawesi, with a discussion of the definition of the genus. Raffles Bull. Zool.,63, 14-26 (2015).

Komolafe, O.O. and G.A.O. Arawomo: Reproductive strategy of Oreochromis niloticus (Pisces: Cichlidae) in Opa reservoir, lle-lfe, Nigeria. Rev. Biol. Trop., 55, 595-602 (2007).

Kovačić, M.: Reproductive biology of the striped goby, Gobius vittatus (Gobiidae) in the Northern Adriatic Sea. Sci. Mar.,71, 145-151 (2007).

Le, T., M.T. Nguyen, V.P. Nguyen, D.C. Nguyen, X.H. Pham, T.S. Nguyen, V.C. Hoang, P.L. Hoang, H. Le and N.C. Dao: Provinces and city in the Mekong Delta. Education Publishing House, Ha Noi (2006).

Longhurst, A.R. and D. Pauly: Ecology of Tropical Oceans. Academic Press, San Diego, United States (1987).

Macinnis, A.J. and L.D. Corkum: Fecundity and reproductive season of the round goby Neogobius melanostomus in the upper Detroit River. Trans. Am. Fish. Soc.,129, 136-144 (2000).

Mazlan, A.G. and M. Rohaya: Size, growth and reproductive biology of the giant mudskipper, Periophthalmodon schlosseri (Pallas, 1770), in Malaysian waters. J. Appl. Ichthyol., 24, 290-296 (2008).

Metin, G., A.T. Ilkyaz, O. Soykan and H.T. Kinacigil: Age, growth and reproduction of four-spotted goby, Deltentosteus quadrimaculatus (Valenciennes, 1837), in İmir Bay (Central Aegean Sea). Turk. J. Zool.,35, 711-716 (2011).

Miller, P.J.: The topology of gobioid fishes. In: Fish Reproduction: Strategies and Tactics (Eds.: G.W. Potts and R.J. Wootton). Academic Press, Orlando, London, United Kingdom, pp. 119-153 (1984).

Nguyen, T.H.D. and Q.M. Dinh: Otolith dimensions and their relationship with the size of Glossogobius sparsipapillus fish along the coastline of Mekong Delta, Vietnam. Egypt. J. Aquat. Biol. Fish.,24, 525-533 (2020). 
Nguyen, T.H.D., H.T.T. Nguyen, T.C. Tran, Y.T.N. Nguyen and Q.M. Dinh: Morphometric and meristic variations of Glossogobius sparsipapillus along the coastline in the Mekong Delta, Vietnam. Int. J. Zool. Animal Biol., 3, 1-9 (2020).

Rainboth, W.J.: Fishes of the Cambodian Mekong.FAO, Roma (1996).

Reavis, R.H.: The natural history of a monogamous coral-reef fish, Valenciennea strigata (Gobiidae): 2. behavior, mate fidelity and reproductive success. Environ. Biol. Fishes. 49, 247-257 (1997).

Riede, K.: The "Global register of migratory species" - first results of global GIS analysis. In: Biological Resources and Migration (Ed.: D. Werner). Springer, Berlin, pp. 211-218 (2004).

Sturm, M.G.d.L.: Aspects of the biology of Scomberomorus maculatus (Mitchill) in Trinidad. J. Fish Biol.,13, 155-172 (1978).

Takegaki, T.: Monogamous mating system and spawning cycle in the gobiid fish, Amblygobius phalaena (Gobiidae). Environ. Biol. Fishes, 59, 61-67 (2000).

Talwar, P.K. and A.G. Jhingran: Inland Fishes of India and Adjacent Countries.A.A. Balkema/Rotterdam, Netherlands (1991).

Teichert, N., P. Valade, A. Fostier, R. Lagarde and P. Gaudin: Reproductive biology of an amphidromous goby, Sicyopterus lagocephalus, in La Réunion Island. Hydrobiologia, 726, 123-141 (2014)

Tran, D.D., K. Shibukawa, T.P. Nguyen, P.H. Ha, X L. Tran, V.H. Mai and K. Utsugi: Fishes of Mekong Delta, Vietnam. Can Tho University
Publisher, Can Tho (2013).

Tran, T.L., S.M. Son, N.M.C. Vo, D.H. Hoang and Q.M. Dinh: Reproductive biology of Periophthalmodon schlosseri (Pallas, 1770) along the coastline in Soc Trang and Bac Lieu. Tap chi Sinh hoc, 41, 229-240 (2019).

Trinh, K. N. and D. D. Tran: The status of capture fisheries and management of marine fishes in Soc Trang Province. Can Tho University J. Sci., 24b, 46-55 (2012).

Udo, M.T.: Morphometric relationships and reproductive maturation of the mudskipper, Periophthalmus barbarus from subsistence catches in the mangrove swamps of IMO estuary, Nigeria. J. Environ. Sc. (China), 14, 221-226 (2002).

Vesey, G. and T.E. Langford: The biology of the black goby, Gobius niger L. in an English south coast bay. J. Fish Biol., 27, 417-429 (1985).

Wootton, R.J.: Ecology of Teleost Fishes. Chapman and Hall, New York, USA(1990).

Yamamoto, K.: Studies on the formation of fish eggs: I. Annual cycle in the development of ovarian eggs in the flounder, Liopsetta obscura. J. Fac. Sci. Hokkaido Univ. Ser. VI. Zool.,12, 362-373 (1956).

Yamazaki, F.: Endocrinological studies on the reproduction of female goldfish, Carassius auratus L., with special reference to the function of pituitary gland. Mem. Fac. Fish. Hokkaido Univ.,13, 164 (1965). 